\title{
ANXA8L1 Gene
}

National Cancer Institute

\section{Source}

National Cancer Institute. ANXA8L1 Gene. NCI Thesaurus. Code C124955.

This gene is involved in binding to calcium and phospholipids. 